\title{
Perencanaan Embung Ohoinol Di Desa Ohoinol Kabupaten Maluku Tenggara
}

\author{
Zakiyatun Nafisah, Dr.techn Umboro Lasminto ST.,M.Sc, Dr.Ir. Edijatno \\ Departemen Teknik Sipil, Fakultas Teknik Sipil dan Perencanaan \\ Institut Teknologi Sepuluh Nopember \\ Jl. Arif Rahman Hakim, Surabaya 60111 Indonesia \\ E-mail: zakiyatun.nafisah95@gmail.com,umboro.lasminto@gmail.com, edijatno@ce.its.ac.id
}

\begin{abstract}
Abstrak-Desa Ohoinol di Maluku Tenggara sering mengalami masalah kekurangan ketersediaan air pada saat musim kemarau. Untuk mengatasi masalah tersebut maka direncanakan untuk dibangun suatu tampungan air yakni embung yang akan berfungsi menampung air saat musim hujan sehingga air dapat digunakan saat musim kemarau. Untuk merencanakan embung dilakukan beberapa analisis. Analisis tersebut meliputi analisis hujan rencana menggunakan distribusi Log Pearson Tipe III , analisis banjir rencana menggunakan metode hidrograf Nakayasu, analisis debit andalan menggunakan metode Mock dan analisis kebutuhan air penduduk Desa Ohoinol. Kebutuhan air terdiri dari kebutuhan air baku domestic dan non dometik dan irigasi. Selain itu dilakukan analisis keseimbangan air menggunakan kapasitas embung untuk melihat apakah tampungan embung mampu memenuhi kebutuhan air, analisis penelusuran banjir menggunakan metode penelusuran waduk dan analisis terhadap keamanan konstruksi bangunan embung.Dari analisis yang telah dilakukan diperoleh besar debit banjir sebesar $10.90 \mathrm{~m}^{3} / \mathrm{s}$ . Nilai rata-rata debit andalan $0.003 \mathrm{~m}^{3} / \mathrm{s}$ untuk Q90\% dan $0.015 \mathrm{~m}^{3} / \mathrm{s}$ untuk Q50\%. Kebutuhan air Desa Ohoinol sebesar 30,990 l/hari untuk air domestik dan 6,260 l/hari non domestik. Nilai tampungan mati embung ohoinol sebesar $12,317.19 \mathrm{~m}^{3}$ dan tampungan efektif $69,797.40 \mathrm{~m}^{3}$. Analisis keseimbangan air yang telah dilakukan menunjukkan embung mampu memenuhi kebutuhan air desa ohoinol. Dari analisis-analisis tersebut maka tubuh embung direncanakan berada padaelevasi dasar $+\mathbf{1 5 . 0 0}$ m sampai elevasi puncak $+25.00 \mathrm{~m}$. Tinggi total tubuh embung adalah 10 dengan kemiringan hulu 2.5 dan kemiringan hilir 2.0. Bangunan pelimpah embung menggunakan mercu tipe ogge, berada pada elevasi +23.00 m dengan lebar mercu 4.0 m. Dari analisis penelusuran banjir, elevasi muka air banjir pada $+\mathbf{2 3 . 8 6}$ m. Kolam olak untuk meredam energi menggunakan USBR tipe III. Konstruksi tubuh embung dan pelimpah telah dianalisis keamanannya dan dinyatakan aman dalam kondisi muka air normal dan muka air banjir.
\end{abstract}

Kata kunci :embung, Maluku Tenggara ,Ohoinol

\section{PENDAHULUAN}

Kabupaten Maluku Tenggara merupakan bagian dari provinsi Maluku yang secara astronomis terletak antara $5^{\circ} 12^{\prime} 19,427^{\prime}{ }^{\prime}-6^{\circ}$ 6' 18.275" Lintang Selatan dan $132^{\circ} 21^{\prime}$ 39,082" - $133^{\circ} 15^{\prime} 31.443$ " Bujur Timur. Kabupaten Maluku Tenggara terdiri 11 kecamatan . salah satunya yakni Kecamatan Kei Kecil. Kecamatan

Kei Kecil sendiri terdiri dari beberapa desa dan salah satunya yakni Desa Ohoinol. Kabupaten Maluku Tenggara memiliki potensi hidrologi berupa sungai dan danau. Sungai yang mengalir di Kabupaten Maluku Tenggara tercatat sebanyak 7 buah. 3 buah berada di Pulau Kei Kecil dan 4 buah di Pulau Kei Besar. Sungai-sungai tersebut mengalirkan air sepanjang tahun. Danau di Kabupaten Maluku Tenggara berada di Pulau Kei Kecil dan berjumlah dua buah yakni Danau Ablel dan Wearlaai[1]. Sebagai bentuk perhatian dari Pemerintah akan pemenuhan kebutuhan air di Provinsi Maluku, beberapa bendungan akan di bangun diantaranya Bendungan Way Apu [2] dan Wae Ela .

Meskipun Kabupaten Maluku Tenggara memiliki potensi hidrologi berupa sungai dan pantai, masih ditemui masalah ketersediaan air. Salah satu daerah yang mengalami masalah tersebut adalah wilayah Kecamatan Kei Kecil Timur tepatnya pada Desa Ohoinol.Saat musim kemarau tiba, air yang tersedia tidak mampu untuk memenuhi kebutuhan masyarakat. Desa Ohoinol sendiri memiliki sumber air dari sungai dan sebenarnya sudah memiliki jaringan air bersih. Namun jaringan air bersih tersebut tidak berfungi akibat masalah pompa dan ketersediaan air.[3] 
Untuk mengatasi ketersediaan air didaerah tersebut, perlu direncakaan sebuah fasilitas yakni embung. Embung ini direncanaakn agar dapat menampung air hujan saat air hujan berlimpah sehingga pada saat musim kemarau ketersediaan air mencukupi dan dapat digunakan. Perencanaan embung ini dipilih karena di Desa Ohoinol memiliki potensi untuk dibangunnya sebuah embung. Potensi yang dimaksudkan yakni berupa aliran sungai dan tebing yang akan digunakan sebagai sandaran tubuh embung. Potensi yang dimakasud tersebut bisa dilihat pada Gambar 1 dan 2.

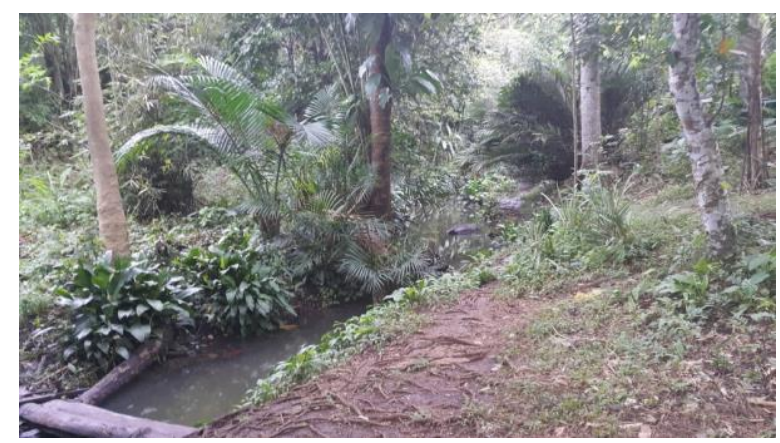

Gambar 1 Aliran Sungai di Lokasi Embung Ohoinol
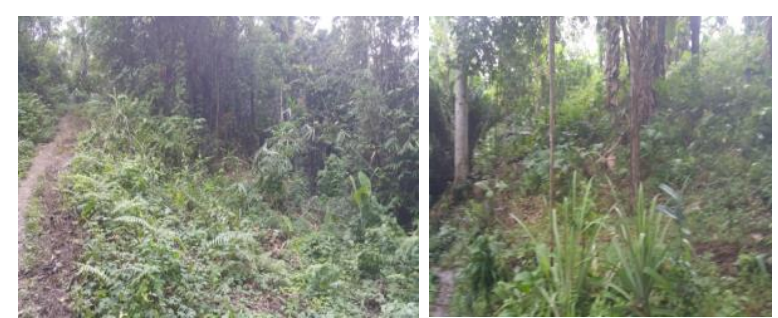

Gambar 2 Tebing Sandaran Kanan dan Kiri Lokasi Rencaan Embung Ohoinol

\section{II.METODE PENELITIAN}

Metode yang dibgunakan dalam perencanaan embung ohoinol dapat dilihat pada Gambar 3.

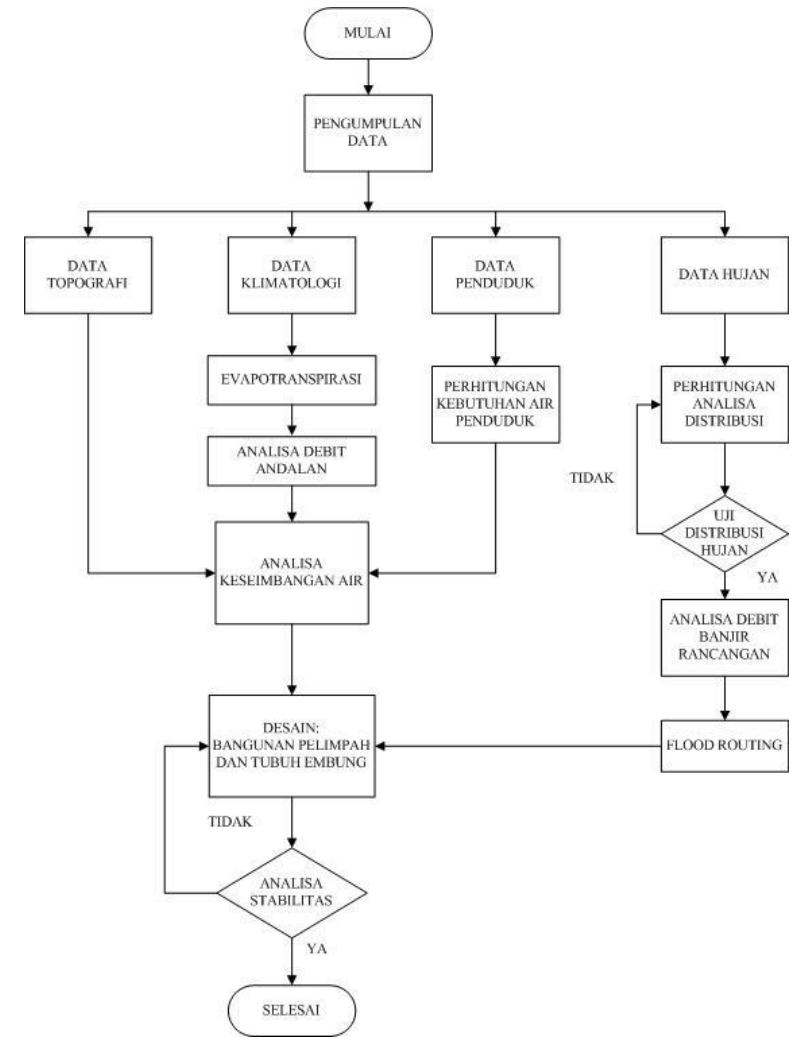

Gambar 3. Diagram alir perencanaan embung ohoinol

\section{HASIL DAN DISKUSI}

\section{A. Analisis distribusi hujan}

Data hujan yang digunakan merupakan hasil pencatatan dari tahun 2001-2015 dan dapat dilihat pada Tabel 1.

Untuk mengetahui distribusi yang tepat untuk analisis data hujan dilakukan analisis parameter statistik [3]. Analaisis parameter statistik terdiri dari:

1. Nilai rata-rata:

$$
\mathrm{Xrt}=\frac{1}{\mathrm{n}} \sum_{\mathrm{i}=1}^{\mathrm{n}} \mathrm{X}_{\mathrm{i}}=\frac{1}{15} 1855=123,67
$$

2. Standar deviasi:

$$
S=\sqrt{\frac{\sum_{i=1}^{n}\left(X_{i}-X r t\right)^{2}}{(n-1)}}=\sqrt{\frac{22343.33}{(15-1)}}=39,95
$$

3. Nilai koefisien kemencengan $(\mathrm{Cs})$

$$
\begin{aligned}
& C s=\frac{n}{(n-1)(n-2)} \frac{\sum_{i=1}^{n}\left(X_{i}-X r t\right)^{3}}{S^{3}} \\
& C s=\frac{15}{(15-1)(15-2)} \frac{43.6806,89}{39.95^{3}}=0,5647
\end{aligned}
$$

4. Nilai koefisien kurtosis (Ck)

$$
\begin{aligned}
& C k \\
& =\left\{\frac{n(n+)}{(n-1)(n-2)(n-3)} \frac{\sum_{i=1}^{n}\left(X_{i}-X r t\right)^{4}}{S^{4}}\right\} \\
& -\frac{3(n-1)^{2}}{(n-2)(n-3)}
\end{aligned}
$$


JURNAL HIDROTEKNIK Vol. 2, No.2, (2017) ISSN : 2477-3212

$$
\begin{aligned}
& C k=\frac{15(15+1)}{(15-1)(15-2)(15-3)} \frac{60997954.44}{39.95^{4}}- \\
& \frac{3(15-1)^{2}}{(15-2)(15-3)}=1.1375
\end{aligned}
$$

5. Nilai rata-rata log tinggi hujan :

$$
\mathrm{Xrt}=\frac{1}{15} 31,08=2,07
$$

6. Nilai standar deviasi (log):

$$
S=\sqrt{\frac{0,26423}{(15-1)}}=0,14
$$

7. Nilai Koefisien Kemencengan (Cs) (log):

$$
C s=\frac{15}{(15-1)(15-2)} \frac{0,0084}{0,14^{3}}=0,2677
$$

8. Nilai Koefisian Kurtosis (Ck) (log)

$$
C k=\left\{\frac{15(15+1)}{(15-1)(15-2)(15-3)} \frac{0,0077}{0,14^{4}}\right\}-\frac{3(15-1)^{2}}{(15-2)(15-3)}=
$$
1,3925

\begin{tabular}{|c|c|c|c|c|c|}
\hline No. & $\begin{array}{c}\text { Jenis } \\
\text { Distribusi }\end{array}$ & Syarat & Per & $\begin{array}{l}\text { asil } \\
\text { tungan }\end{array}$ & Keputusan \\
\hline \multirow{2}{*}{1} & \multirow{2}{*}{$\begin{array}{c}\text { Distribusi } \\
\text { Normal }\end{array}$} & $\mathrm{Cs} \approx 0$ & Cs & 0,5647 & $\begin{array}{c}\text { Tidak } \\
\text { Diterima }\end{array}$ \\
\hline & & $\mathrm{Ck}=3$ & $\mathrm{Ck}$ & 2,4672 & $\begin{array}{c}\text { Tidak } \\
\text { Diterima }\end{array}$ \\
\hline \multirow{2}{*}{2} & \multirow{2}{*}{$\begin{array}{l}\text { Distribusi } \\
\text { Gumbell }\end{array}$} & $\begin{array}{l}\mathrm{Cs} \approx \\
1,14\end{array}$ & Cs & 0,5647 & $\begin{array}{c}\text { Tidak } \\
\text { Diterima }\end{array}$ \\
\hline & & $\begin{array}{l}\mathrm{Ck} \approx \\
5,40\end{array}$ & $\mathrm{Ck}$ & 2,4672 & $\begin{array}{c}\text { Tidak } \\
\text { Diterima }\end{array}$ \\
\hline \multirow{2}{*}{3} & \multirow{2}{*}{$\begin{array}{c}\text { Distribusi } \\
\text { Log Pearson } \\
\text { III }\end{array}$} & $\begin{array}{c}\text { Cs } \\
\text { bebas }\end{array}$ & Cs & 0,2677 & Diterima \\
\hline & & $\begin{array}{c}\mathrm{Ck} \\
\text { bebas }\end{array}$ & $\mathrm{Ck}$ & 2,2282 & Diterima \\
\hline
\end{tabular}

Tabel 1

Hujan maksimum dari tahun 2001-2015

\begin{tabular}{ccc}
\hline No & Tahun & $\begin{array}{c}\text { Hujan Maksimum } \\
(\mathbf{m m})\end{array}$ \\
\hline 1 & 2001 & 128 \\
2 & 2002 & 75 \\
3 & 2003 & 89 \\
4 & 2004 & 99 \\
5 & 2005 & 89 \\
6 & 2006 & 186 \\
7 & 2007 & 128 \\
8 & 2008 & 94 \\
9 & 2009 & 193 \\
10 & 2010 & 118 \\
11 & 2011 & 173 \\
12 & 2012 & 91 \\
13 & 2013 & 83 \\
14 & 2014 & 143 \\
15 & 2015 & 166 \\
\hline
\end{tabular}

Tabel 2

Syarat dan penentuan jenis distribusi hujan

Analisis distribusi hujan menggunakan distribusi Log Pearson tipe III. Tinggi hujan rencana dengan periode ulang 100 tahun dengan perhitungan metode adalah 261,89 $\mathrm{mm}$.

\section{B. Analisis hujan efektif setiap jam}

Data hujan pada Tabel 1 merupakan tinggi hujan harian $\left(\mathrm{R}_{24}\right)$. Untuk mendapatkan nilai hujan efektif, nilai hujan harian dikalikan koefisien lahan sebesar 0,5. tinggi hujan efektif $\mathrm{R}_{24}$ untuk periode ulang 100 tahun adalah $0,5 \times 261,89 \mathrm{~m}=130,94 \mathrm{~mm}$.

\section{Analisis debit banjir rencana}

Anlisis debit banjir rencana dengan menggunakan metode hidrograf satuan sintesis Nakayasu dengan waktu hujan selama 6 jam. Untuk Q 100 tahun diperoleh debit sebesar 10,90 $\mathrm{m}^{3} / \mathrm{s}$. Hidrograf banjir Nakayasu dapat dilihat pada Gambar 4.

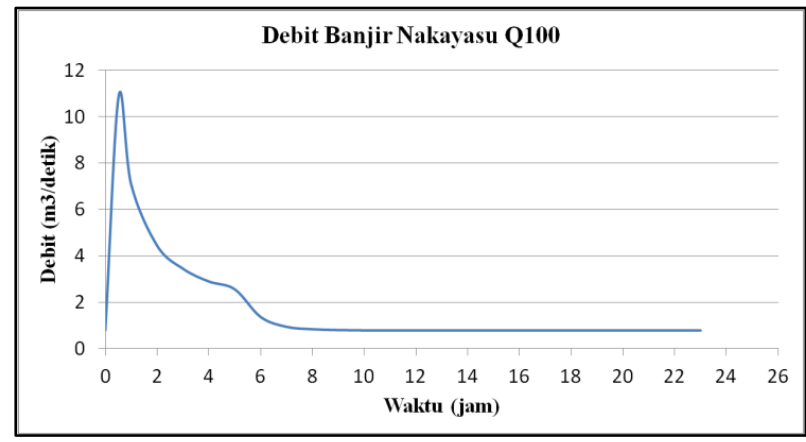

Gambar 4 Hidrograf banjir metode nakayasu

\section{Evapotranspirasi penman}

Dari analisis perhitungan evapotranspirasi menggunakan metode penman didapatkan hasil seperti pada Tabel 3.

Tabel 3

\begin{tabular}{cc}
\multicolumn{3}{c}{ Evpotranspirasi Penman } \\
\hline Bulan & ETo (mm/hari) \\
\hline Januari & 5,25 \\
Februari & 5,36 \\
Maret & 4,98 \\
April & 4,60 \\
Mei & 4,81 \\
Juni & 4,76 \\
Juli & 5,29 \\
Agustus & 6,36 \\
September & 6,87 \\
Oktober & 7,02 \\
Nopember & 5,74 \\
Desember & 4,53 \\
\hline
\end{tabular}

E. Analisis ketersediaan air

Debit andalan dihitung dengan menggunakan metode FJ.Mock dan didaptkan hasil seperti pada Tabel 4. Lengkung kapasitas tampungan embung dapat dilihat 
pada Gamabr 4. Elevasi mercu pelimpah direncanakan berada pada $+23,00$ sehingga kapasitas tampungan total embung 82.115,59 $\mathrm{m}^{3}$, tampungan mati $12.317,19$ dan tampungan efektif 69.797,40. Grafik lengkung kapasitas embung dapat dilihat pada Gambar 5

Tabel 4 Debit Andalan Mock

\begin{tabular}{ccc} 
Bulan & $\begin{array}{c}\text { Debit } \mathbf{( 9 0 \% )} \\
\mathbf{~ m}^{\mathbf{3} / \mathbf{s}}\end{array}$ & $\begin{array}{c}\text { Debit (rerata) } \\
\mathbf{~ m}^{\mathbf{3}} \mathbf{s}\end{array}$ \\
\hline Januari & 0,006 & 0,030 \\
Pebruari & 0,004 & 0,024 \\
Maret & 0,010 & 0,029 \\
April & 0,005 & 0,029 \\
Mei & 0,000 & 0,013 \\
Juni & 0,000 & 0,013 \\
Juli & 0,000 & 0,002 \\
Agustus & 0,000 & 0,001 \\
September & 0,000 & 0,001 \\
Oktober & 0,000 & 0,001 \\
Nopember & 0,000 & 0,006 \\
Desember & 0,007 & 0,032 \\
\hline
\end{tabular}

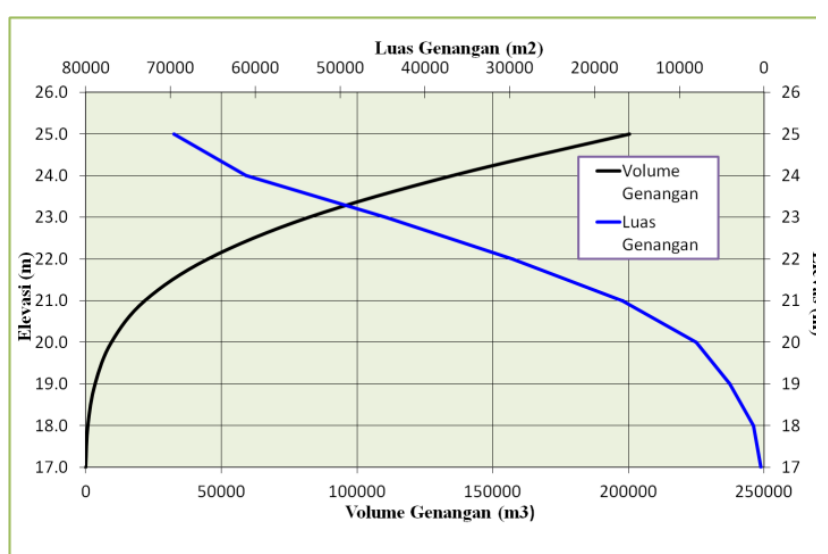

Gambar 5 Grafik hubungan antara elevasi, volume dan luas genangan

\section{F. Analisis kebutuhan air penduduk Ohoinol}

Jumlah penduduk Desa Ohoinol pada tahun 2014 adalah 393. Pertumbuhan penduduk diasumsikan sebesar 1,3 setiap tahun. Dengan menggunakan proyeksi penduduk metode eksponensial diperoleh jumlah penduduk pada tahun 2043 sebagai berikut:

$$
\begin{aligned}
\text { Pn } & =\text { Po } \mathrm{e}^{\mathrm{rn}} \\
& =393 \mathrm{e}^{1.3 / 100 \times 26} \\
& =544 \text { jiwa }
\end{aligned}
$$

- Kebutuhan air domestik :

- Kebutuhan air untuk saluran rumah $(\mathrm{SR})=60$ 1/org/hari

- Kebutuhan air untuk hidran umum $(\mathrm{HU})=30$ 1/org/hari
- Kehilangan air $==30 \%$ dari total kebutuhan.

- Kebutuhan air non domestik : dapat dilihat pada Tabel 5.

Tabel 5

Kebutuhan air non domestik

\begin{tabular}{cccc}
\hline Fasilitas & Jumlah & Kebutuhan air & $\begin{array}{c}\text { Total } \\
\text { kebutuhan air }\end{array}$ \\
\hline SD & 50 siswa & $101 /$ siswa/hari & $5001 /$ hari \\
SLTP & 50 siswa & $101 /$ siswa/hari & $5001 /$ hari \\
SLTA & 80 siswa & $101 /$ siswa/hari & $8001 /$ hari \\
puskesmas & 1 & $20001 /$ hari & $20001 /$ hari \\
Gereja & 1 & $101 /$ hari & $101 /$ hari \\
Pasar & $1(0.2 \mathrm{Ha})$ & $120001 /$ ha/hari & $24001 /$ hari \\
Kios & 5 & $101 /$ hari & $501 /$ hari \\
& Jumlah & & $6,2601 /$ hari \\
\hline
\end{tabular}

Kebtutuhan irigasi : Pola tanam yang duganakan adalah pola tanaman palawijapalawija-palawija. Musim tanam pertama dimulai pada setengah bulan pertama bulan Januari.Kebutuhan air untuk tiap setengah bulan adalah dapat dilihat pada Tabel 6

Tabel 6

Kebutuhan air untuk irigasi

\begin{tabular}{ccc}
\multicolumn{3}{c}{ Kebutuhan air untuk irigasi } \\
\hline Bulan & I & II \\
\hline Januari & 0.00 & 0.00 \\
Pebruari & 0.00 & 0.00 \\
Maret & 0.00 & 0.00 \\
April & 0.00 & 0.00 \\
Mei & 0.00 & 0.06 \\
Juni & 0.07 & 0.00 \\
Juli & 1.07 & 0.00 \\
Agustus & 1.28 & 0.00 \\
September & 0.88 & 0.95 \\
Oktober & 1.23 & 0.00 \\
Nopember & 1.03 & 0.00 \\
Deseber & 0.00 & 0.00
\end{tabular}

G. Analisis Keseimbangan air

Untuk melihat apakah tampungan embung ohoinol mampu mencukupi kebutuhan air penduduk,maka dilakukan analisis keseimbangan air. Analisis keseimbangan air pertama adalah untuk kebutuhan air baku saja dengan menggunakan debit andalan 90\%. Dari analisis yang dilakukan tampungan air mampu mencukupi kebutuhan air baku dengan tingkat prosentasi penduduk terlayani $64 \%$. analisis keseimbangan air yang kedua dengan menggunakan debit andarlan rata-rata. Dari analisis tersebut tampugan air mampu memenuhi kebutuhan air domestik dengan tingkat pelayanan $100 \%$, kebutuhan non 
domestik dan kebutuhan irigasi untuk luas area tanam 3,0 Ha.

\section{H. Analisis Penelusuran Banjir}

Analisis penelusuran banjir dengan metode penelusuran waduk dimana aliran keluar melalui pelimpah. Pelimpah direncanakan memliki lebar 4,0 $\mathrm{m}$ dan koefisien debit (C) 2,16. Maka debit yang keluar melalui pelimpah dihitung dengan persamaan :

$$
\mathrm{Q}=\mathrm{CBH}^{1.5}=2,16 \times 4,0 \mathrm{~m} \mathrm{x} \mathrm{H} \mathrm{H}^{1,5}
$$

Dari hasil penelusuran banjir diperoleh data inflow maksimum $10.90 \mathrm{~m}^{3} / \mathrm{s}$ dan outflow maksimum $7.64 \mathrm{~m}^{3} / \mathrm{s}$ pada elevasi $23.86 \mathrm{~m}$. Tinggi air di atas pelimpah $0.86 \mathrm{~m}$. Hidrograf inflow dan outflow bisa dilihat pada Gambar 6.

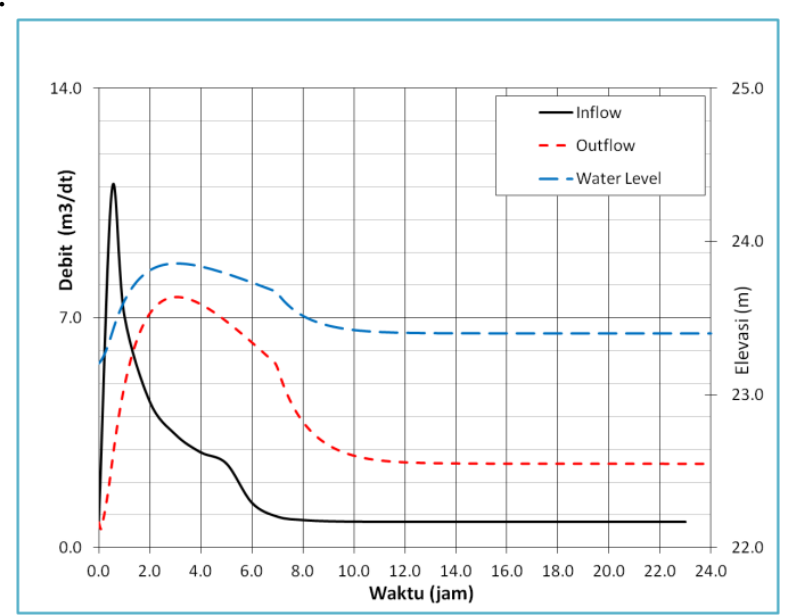

Gambar 6 Hidrograf Inflow, outflow dan elevasi muka air

\section{Perencanaan Pelimpah}

Bangunan pelimpah embung ohoinol direncanakan menggunakan debit banjir periode ulang 100 tahun yakni sebesar 10,90 $\mathrm{m}^{3} / \mathrm{s}$. bangunan pelimpah terdiri dari saluran pengarah aliran, mercu pelimpah, saluran transisi, saluran peluncur dan bangunan predam energi. Skema perencanaan dapat dilihat pada Gambar 7. Pelimpah direncanakan menggunakan tipe ogee dapat dilihat pada Gambar 8[4]. Puncak mercu pelimpah pada elevasi $+23,00 \mathrm{~m}$. dasar pelimpah pada elevasi $+22,00 \mathrm{~m}$. Bangunan peredam energi menggunakan kolam olak USBR tipe III. Alasan pemilihan tipe ini karena angka Froude aliran 7,83> 4,5, kecepatan aliran $11,79 \mathrm{~m} / \mathrm{s}<18,0 \mathrm{~m} / \mathrm{s}$ dan debit air yang mengalir $<18,5 \mathrm{~m}^{3} / \mathrm{s}[5]$. Detail kolam olak dapat dilihat pada Gambar 9.

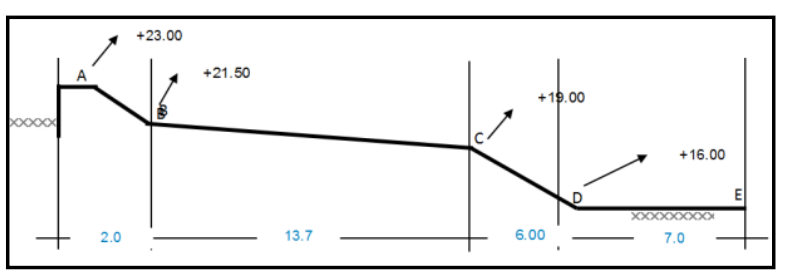

Gambar 7 Perencanaan bangunan pelimpah

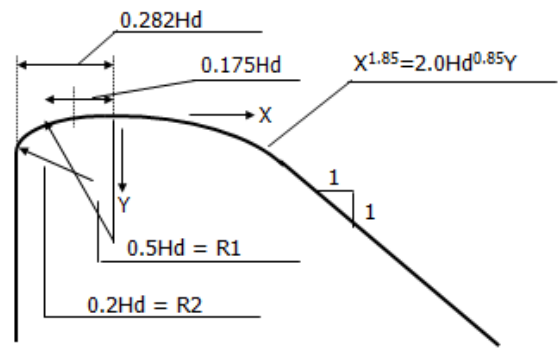

Gambar 8 Kriteria pelimpah tipe ogee

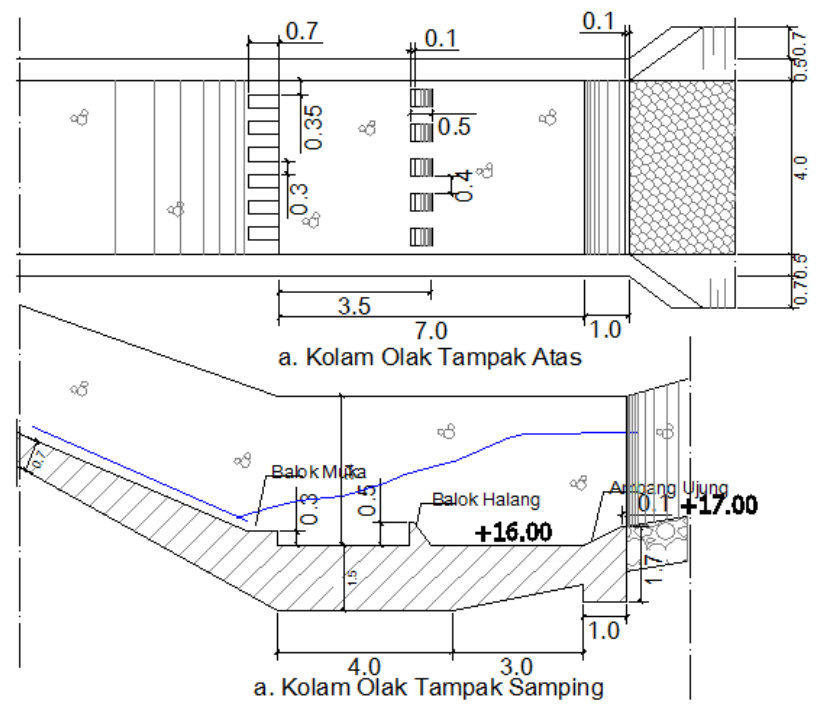

Gambar 9 Detail kolam olak USBR tipe III

\section{J. Analisis Stabilitas Pelimpah}

Analisis stabilitas pelimpah dilakukan dalam 4 kondisi yakni pada saat mua air normal (MAN) dan pada saat muka air banjir (MAB) baik tanpa gempa yakni kondisi (1) maupun dengan gempa yakni kondisi (2). SF pada kondisi tanpa beban gempa adalah 1,3 sedangkan kondisi dengan beban gempa adalah 1,1. [5]

- Kontrol Guling
$S F=\frac{M \text { tahanan }}{M \text { guling }}$

- Kontrol terhadap gaya geser: 


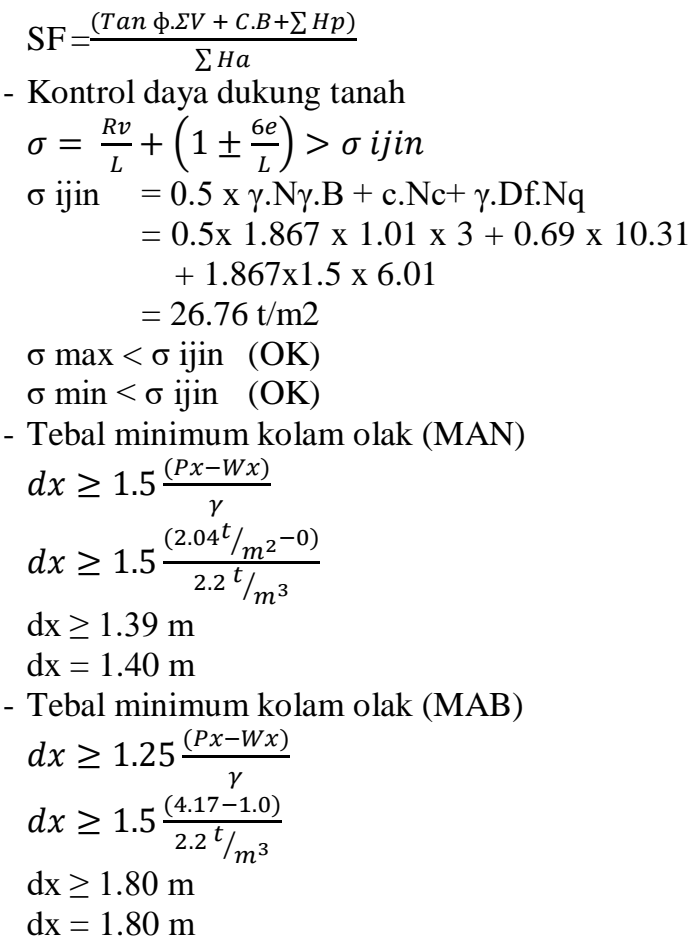

Tabel 7

\begin{tabular}{ccccccc}
\multicolumn{7}{c}{ Hasil perhitungan Stabilitas Pelimpah } \\
\hline Kondisi & $\begin{array}{c}\text { MAN } \\
\mathbf{1}\end{array}$ & MAN2 & Ket & MAB1 & $\begin{array}{c}\text { MAB } \\
\mathbf{2}\end{array}$ & Ket \\
\hline $\begin{array}{c}\text { Kontrol } \\
\text { guling }\end{array}$ & 2,65 & 1,74 & Ok & 1,36 & 1,21 & Ok \\
$\begin{array}{c}\text { Kontrol } \\
\text { geser }\end{array}$ & 4,70 & 2,56 & Ok & 4,90 & 2,79 & Ok \\
$\begin{array}{c}\text { Daya } \\
\text { dukung }\end{array}$ & 5,59 & 3,95 & Ok & 9,64 & 13,29 & OK \\
\hline
\end{tabular}

\section{K. Perencanaan Tubuh Embung}

Tubuh embung terdiri dari tiga zona yakni inti, random dan rip-rap. tinggi tubuh embung $10 \mathrm{~m}$. Dasar embung berada pada $+15,00 \mathrm{~m}$ dan puncak bendung berada pada $+25,00$. Untuk analisa stabilitas bendung pertama dilakukan perhitungan analisa garis depresi. Karena timbunan merupakan timbunan heterogen maka perhitungan garis depresi dilakukan dua kali yakni pada saat melewati zona inti dan pada saat melewati zona random.

Persamaan garus depresi:

$$
y=\sqrt{2 y_{o} x+} y_{o}^{2}
$$

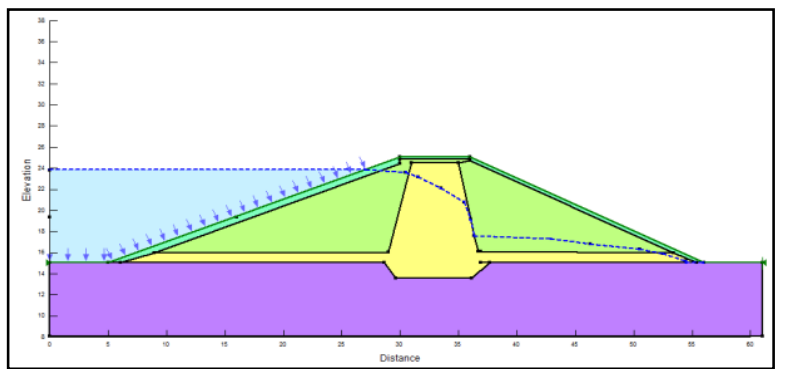

Gambar 10 Contoh garis depresi pada saat muka air banjir

Analisis stabilitas lereng dilakukan dengan menggunakan bantuan program bantu geoslope. Contoh hasil analisis kelongsoran dapat dilihat pada Gambar 11 sedangkan hasil analisis dapat dilihat pada Tabel 8.

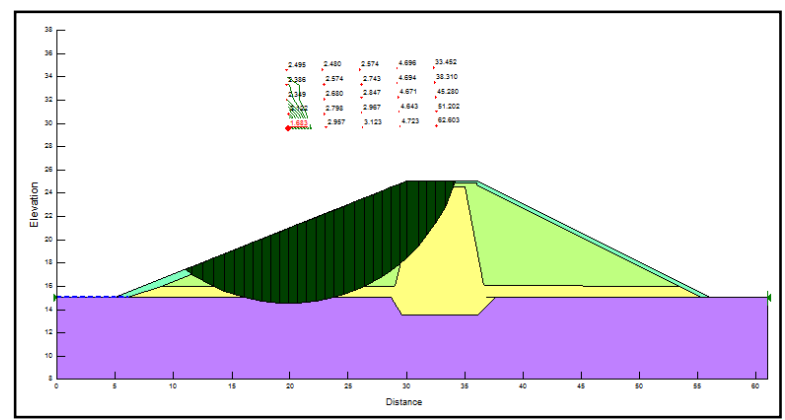

Gambar 11 Hasil analisis bidang longsor bagian hulu saat embung kosong.

Tabel 8

Hasil analisis keamanan konstruksi tubuh embung

\begin{tabular}{|c|c|c|c|c|}
\hline \multirow[b]{2}{*}{ kondisi } & \multicolumn{4}{|c|}{ Tanpa beban gempa } \\
\hline & hulu & hilir & $\begin{array}{c}\mathrm{SF} \\
\text { rencana }\end{array}$ & Ket \\
\hline Embung kosong & 1,683 & 1,966 & 1,3 & OK \\
\hline Muka air banjir & 1,863 & 1,734 & 1,3 & OK \\
\hline $1 / 2$ muka air banjir & 1,431 & 1,528 & 1,3 & OK \\
\hline \multirow[t]{2}{*}{ Rapid drawdown } & 1,126 & 1,308 & 1,1 & OK \\
\hline & \multicolumn{4}{|c|}{ Dengan beban gempa } \\
\hline kondisi & hulu & hilir & $\begin{array}{c}\text { SF } \\
\text { rencana }\end{array}$ & Ket \\
\hline Embung kosong & 1,240 & 1,301 & 1,1 & OK \\
\hline Muka air banjir & 1,134 & 1,371 & 1,1 & OK \\
\hline $1 / 2$ muka air banjir & 1,134 & 1,171 & 1,1 & $\mathrm{OK}$ \\
\hline
\end{tabular}

\section{KESIMPULAN}

1. Berdasarakan analisa perhitungan debit andalan ketersediaan air embung ohoinol dengan menggunakan metode FJ Mock diperoleh besar debit andalan rata-rata untuk debit andalan 90\% adalah 0,003 $\mathrm{m}^{3} /$ detik dan untuk debit andalan $50 \%$ adalah $0,015 \mathrm{~m}^{3} /$ detik. Sedangkan berdasarkan lengkung kapasitas, embungn ohoinol memiliki kapasitas 
tampungan efektif $12,317.19 \mathrm{~m}^{3}$ dan tampungan mati $69,797.40 \mathrm{~m}^{3}$.

2. Kebutuhan air baku desa ohoinol sebagai berikut:

- Air domestik : 30,990 1/hari,

- non domestik : 6,260 1/hari,

- kehilangan (30\%) :11,170 1/hari

- total : 48,425 1/hari atau 0,0006 $\mathrm{m}^{3} /$ detik

3. Berdasarkan analisa keseimbangan air, kebutuhan air baku domestik desa ohoinol dengan menggunakan debit andalan 90\% dapat terpenuhi dengan tinggkat pelayanan $64 \%$. Sedangkan jika menggunakan debit andalan 50\% dapat memenuhi kebutuhan air baku domestik dengan tingkat pelayanan $100 \%$, kebutuhan air non domestik dan kebutuhan air irigasi untuk luas sawah sebesar 3,00 Ha.

4. Analisis hidrologi menggunakan distribusi Pearson Tipe III. Untuk debit banjir dengan periode ulang 100 tahun diperoleh besaran nilai $10.9 \mathrm{~m} 3 /$ detik dengan menggunakan metode Nakyasu.

5. Berdasarkan hasil analisa perhitungan perencanaan dan analisa stabilitas bangunan embung didapatkan :

- Dimensi tubuh embung:

Tipe = tipe urugan

Tinggi $=10,0 \mathrm{~m}$

Lebar mercu $\quad=6,0 \mathrm{~m}$

Lebar dasar $=51 ., \mathrm{m}$

Elevasi mercu $=+25,00 \mathrm{~m}$

Elevasi dasar $=+15,00 \mathrm{~m}$

Kemiringan hulu $=2,5$

Kemiringan hilir $=2,0$

- Dimensi pelimpah dan pelengkap

Tipe mercu = Mercu tipe ogee

Lebar pelimpah $=4,0 \mathrm{~m}$

Tinggi pelimpah $=1.0 \mathrm{~m}$

Panjang saluran transisi $=13,7 \mathrm{~m}$

Panjang saluran peluncur $=6,0 \mathrm{~m}$

Lebar saluran peluncur $=4,0 \mathrm{~m}$

Elevasi mercu pelimpah $=+23,00 \mathrm{~m}$

Elevasi dasar pelimpah $=+22,00 \mathrm{~m}$

Panjang kolam olak $=7,0 \mathrm{~m}$

Tipe kolam olak $=$ USBR Tipe III

\section{DAFTAR PUSTAKA}

[1] Badan Pusat Statitik Kabupaten Maluku Tenggara.2015. Maluku Tenggara Dalam Angka 2015. Maluku Tenggara: BPS.

[2] Cahyadi, A. D. Lasminto, U. dan Ansori, M. B. Redesain Bendungan Way Apu Kabupaten Buru Provinsi Maluku. Jurnal Hidroteknik, vol. 1, no. 2, pp 67-74. 2015.

[3] Firma Angel Consulting Engineering. 2016. SID Pengembangan Waduk Kecil/Embung Serba Guna Untuk Konservasi SDA dan Ketahanan Air Kab.Maluku Tenggara

[4] Soewarno. 1995. Hidrologi Aplikasi Metode Statistik untuk Analisis Data jilid 1. Bandung:Nova.

[5] Suyono.,Kensaku Takeda. 2002. Bendungan Type Urugan. Jakarta:PT Pradnya Paramita

[6] Pekerjaan Umum, Dirjen. 1986. Kriteria Perencanaan 02-Bangunan Utama. Jakarta: PU. 